\title{
The Effect of Peer-Based Education on the Psychological Burden of Family Caregivers of Patients with Schizophrenia Admitted to the Military Hospital
}

Lami B 1

Rajai N 2*

Pishgooie $\mathrm{SAH}^{3}$

Habibi $\mathrm{H}^{4}$

Manochehri Z 5

1- MSc Student Psychiatric Nursing, Student Research Committee, Faculty of Nursing, Aja University of Medical Sciences, Tehran, Iran.

2- ( ${ }^{*}$ Corresponding Author) MSC in Nursing, Instructor, Maternal Newborn Department, Faculty of Nursing, Aja University of Medical Sciences, Tehran, Iran.

Email:n.rajai22@yahoo.com

3- Ph.D. in Nursing, Assistsnt Professor, Medical-Surgical Department, Faculty of Nursing, Aja University of Medical Sciences, Tehran, Iran.

4- MSC in Nursing, Instructor, Pediatric Department, Faculty of Nursing, Aja University of Medical Sciences, Tehran, Iran.

5- MSC in Clinical Psychologist, Naval Health Department, Tehtan, Iran.

\section{Abstract}

Introduction: Psychosocial stresses and stresses caused by schizophrenic patients are a significant but common practice that, if left untreated and intervened, can lead to a reduction in the physical and mental health of family caregivers as hidden patients, and The quality of care they provide is effective.

Objectives: The purpose of this study was to determine the effect of peer-centered education on psychological burden on family caregivers of schizophrenic patients.

Materials and Methods: This study was a clinical trial performed on 64 family caregivers of patients admitted to the military hospital with schizophrenia in 2018. Patients were selected using a purpose-based method and randomly divided into two groups of test and control. For the experimental group, peer educator training was performed for 6 sessions and the control group did not take any action. Finally, the psychological burden of the two groups was compared. P less than 0.05 was considered as a significant level.

Result: There were no significant differences between the two test groups between the two variables. In the pre-intervention stage, the mean psychological burden was not significantly different in the two groups of test and control, while immediately and two weeks after the intervention, this difference was significant $(\mathrm{P}<0.001)$. Also, the results of the ANOVA test showed significant differences between the two groups $(\mathrm{P}<0.001)$.

Discussion and Conclusion: Considering the average level of mental burden of the samples in this study and considering that the results of this study indicate the positive effects of peer-to-peer education on the psychological burden of families of schizophrenic patients, it is recommended to use successful experiences of peers as a model with Creating empathy between educator and learner to reduce the psychological burden of families of schizophrenic patients in hospitals and after discharge.

Keywords: Education, Schizophrenia, Psychological burden, Patient, Family.

Cod IRCT: IRCT2018122180420040N1 


\section{بررسى تأثير آموزش همتا محور بر بار روانى مراقبين خانوادتى بيماران مبتلا به اسكيزوفرنيا بسترى در بيمار ستان منتخب نظامى

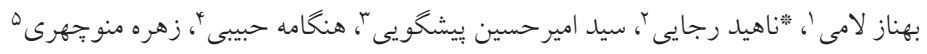

جكيده

مقدمه: تنشها و فشارهاى روانى ناشى از مراقبت از بيمار اسكيزوفرن امرى قابل توجه و در عين حال معمول است كه

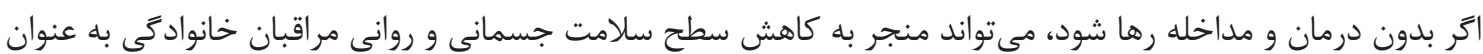
بيماران ينهان شود و بر كيفيت مراقبتى كه ارائه مى دهند مؤثر باشد.

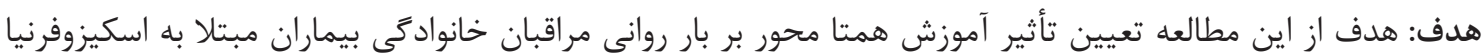
مىباشد.

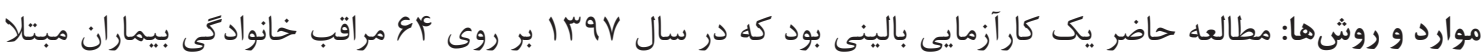

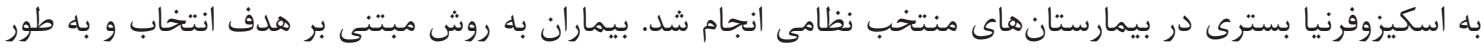

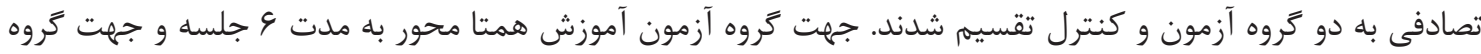

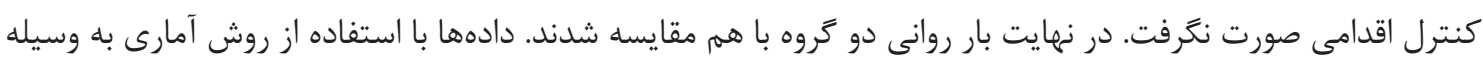

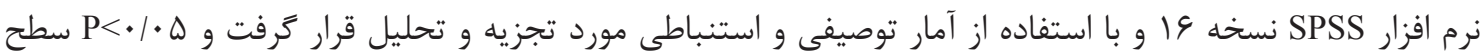
معنى دارى در نظر كرفته شد.

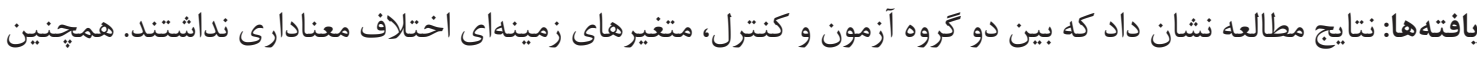

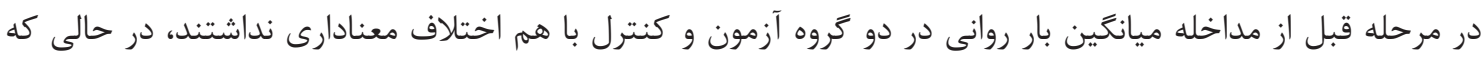

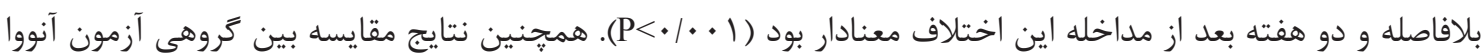

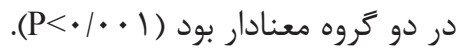
بحث و نتيجهَّيرى: با توجه به سطح متوسط بار روانى نمونهاى اين مطالعه و نظر به اينكه نتايج اين مطالعه حاكى

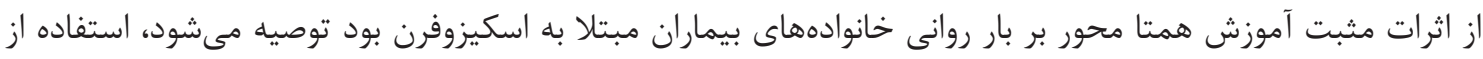

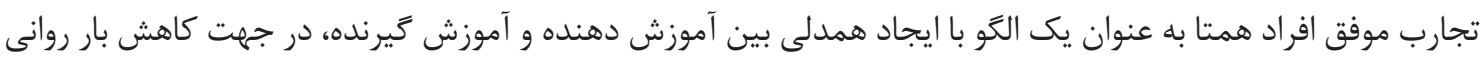
خانوادههاى بيماران اسكيزوفرن در بيمارستانها و بعد از ترخيص استفاده شود. كلمات كليدى: آموزش، اسكيزوفرنيا، بار روانى، بيمار، خانوادها

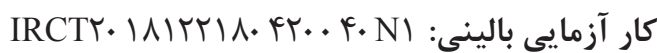

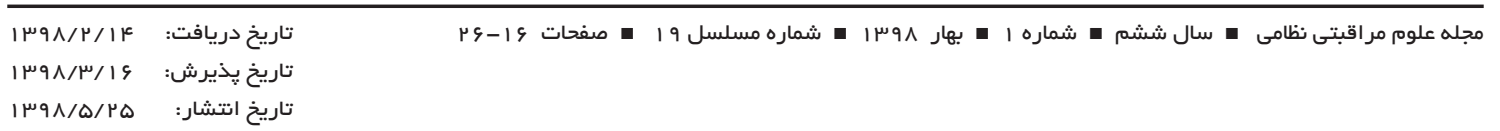

را تحت تأثير قرار مىدهد. به طور كلى علائم اسكيزوفرنى به دو مزمن روانيزشكى است كه همه ابعاد جسمى، روانى و رفتارى بيمار 
يا مجموعه فشارهاى حاصل از مراقبت يك بيمار است كه به مراقب

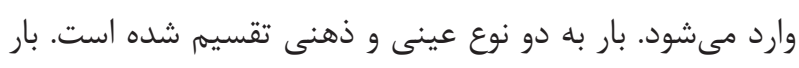

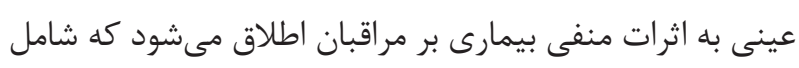

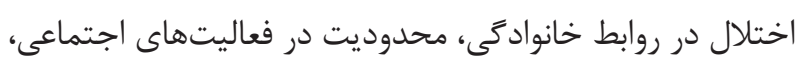

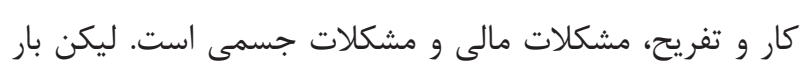

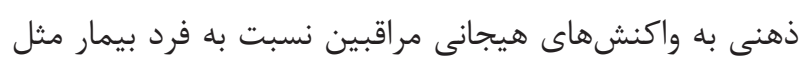

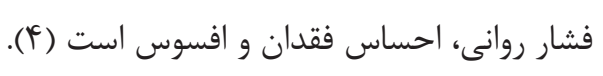

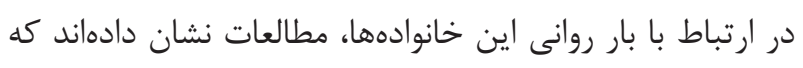

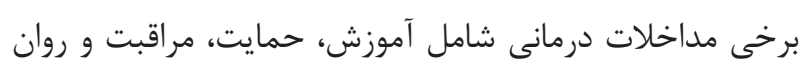

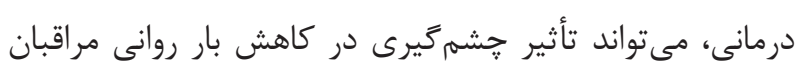

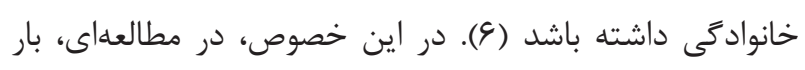

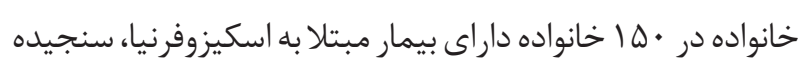
شده و عوامل مؤثر بر آن بررسى كرديد كه طى آن دارئ نتايج نشان داد: ا - مراقبان، بار را در سطح هيجانى و عملى تجربه مئ كر كردند. ץ- همبستگى مثبتى بين ميزان رفتارهاى بيمار گَونه بيمار و بار

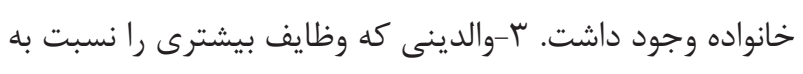

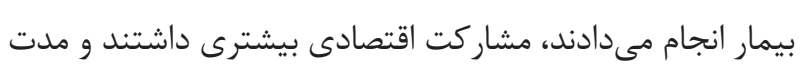

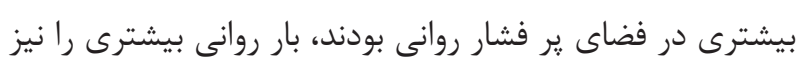

$$
\text { نشان دادند (V). }
$$

همان طور كه قبلاً اشاره كرديد، مراقبان خانوادَى به عنوان افراد

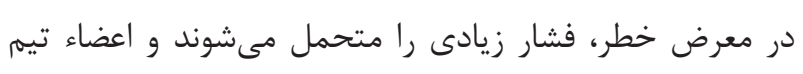

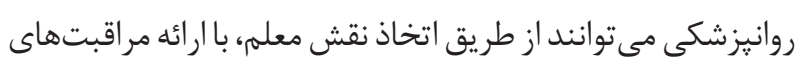

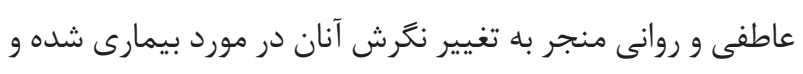
از شدت استرس و فشار روحى روانى آنان بكاهند و سلامتى روان

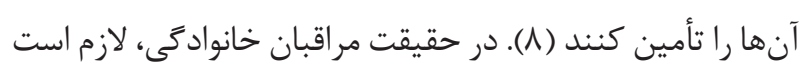

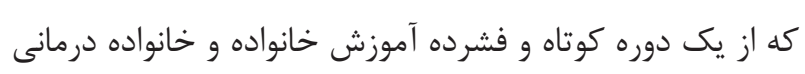

برخوردار شود (ه). در ارتباط با آموزش مر اقبان، آموزش همتا محور رويكردى است است كه

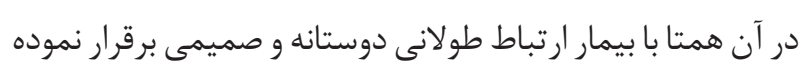

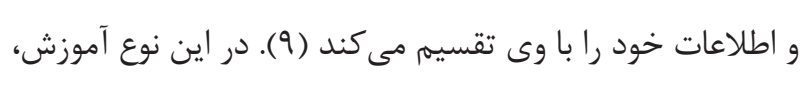

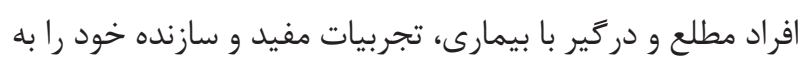

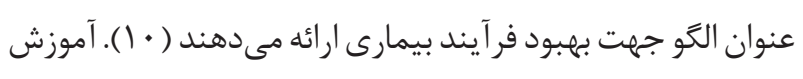

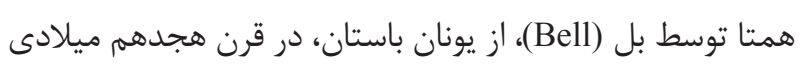

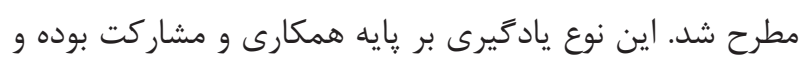

عواطف، كم حرف شدن، بى تفاوتى و بىارادگى تقسيم مىشود

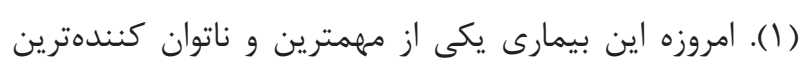

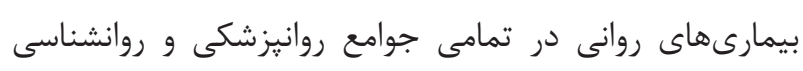

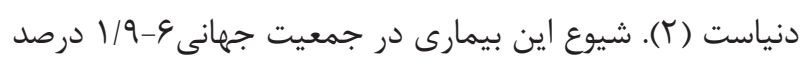

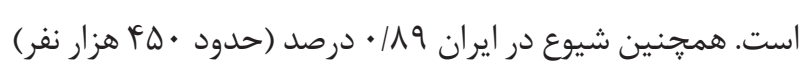

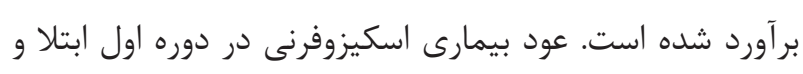

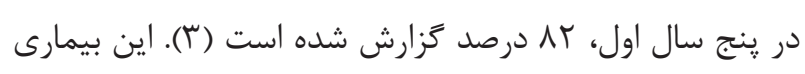

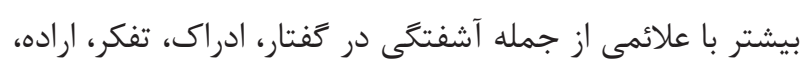

عاطفه و فعاليت اجتماعى آشكار مىشود (1).

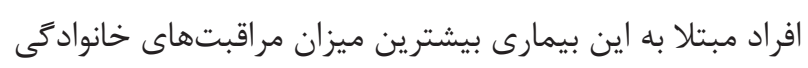

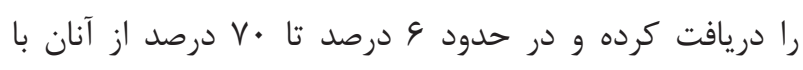

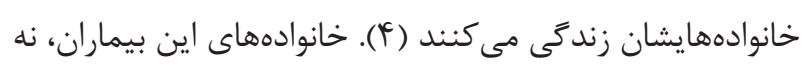

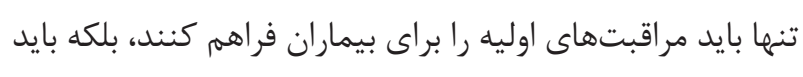

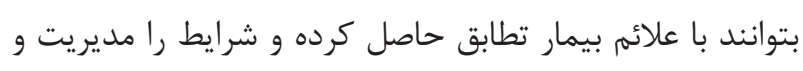

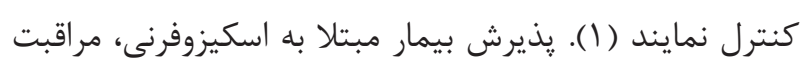
از وى در مصرف دارو، ايجاد فضاى آرام، مثبت و سازنده، يرهيز

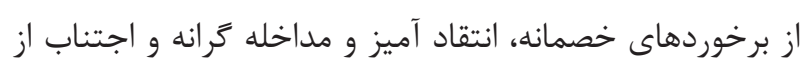
وابسته كردن بيمار از عمده وظايفى است كه خانوادههاى اين بيماران بايد به آن توجه داشته باشند (ه). در كنار مراقبتهار آندا، بار

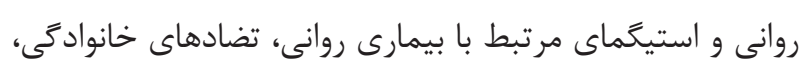
مشكلات مالى، انزواى اجتماعى و كمبود حمايت اجتماعى، از

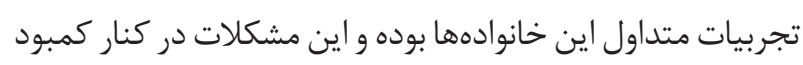

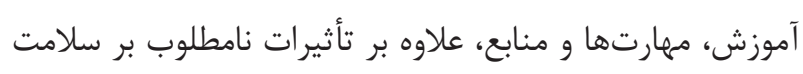

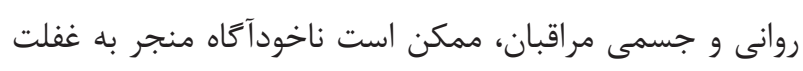

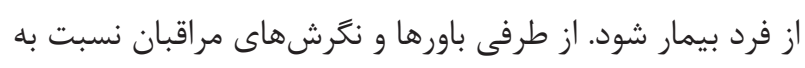

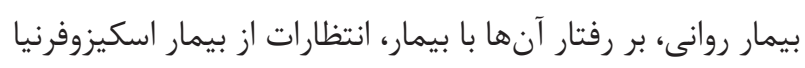

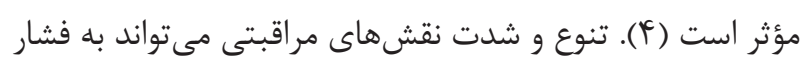

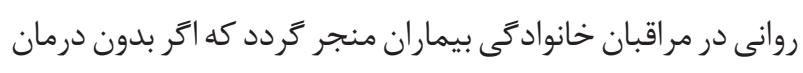

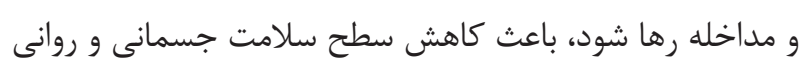

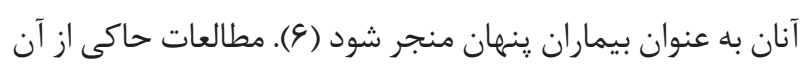

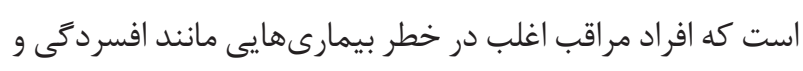

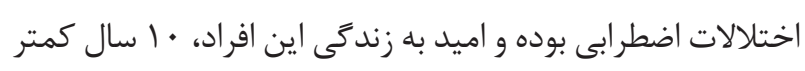

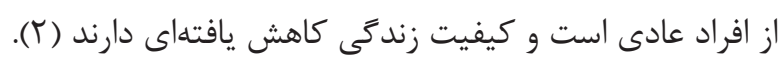
از جمله مهمتر ين مشكلات اين خانوادهها، بار (Family Burden) 
جهت اجراى يزوهش ابتدا يس از تائيد پرويوزال در شوراى يزوهشى

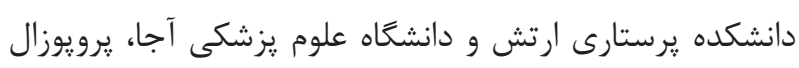

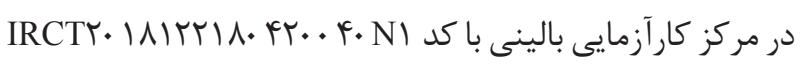

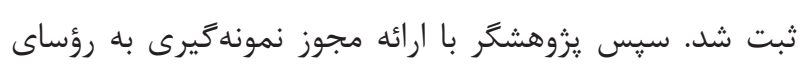

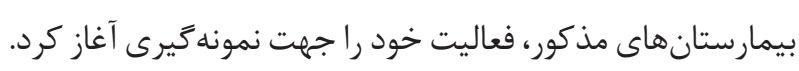

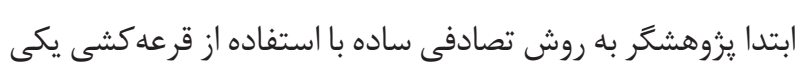

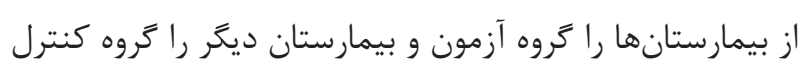
خود قرار داد. يزوهشكر جهت دسترسى به خانوادههاى بيماران

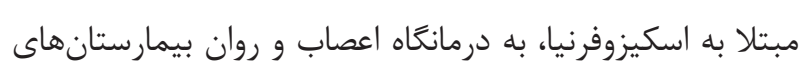
مذكور مراجعه نموده، روزانه در شيفت صبح و با اجازه مسئول

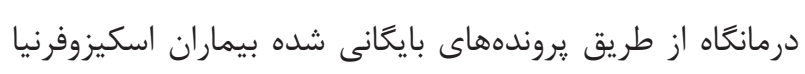
به شماره تلفن خانوادههاى بيماران اسكيزوفرنيا دسترسى يُ ريدا

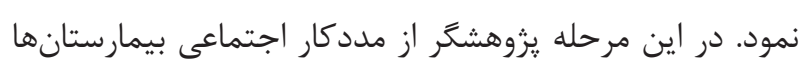

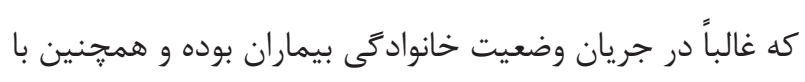

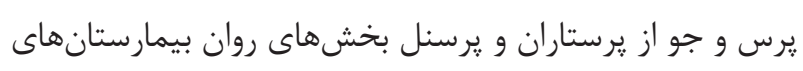

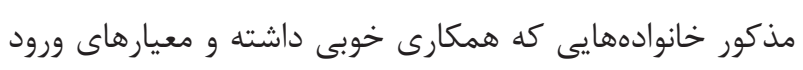

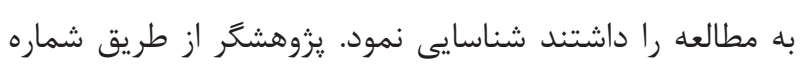

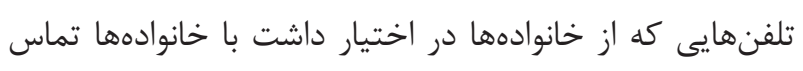

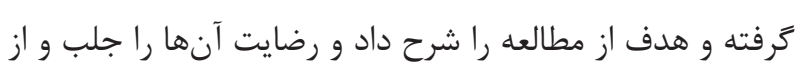
خانوادهها دعوت به همكارى در يزوهش كرد.

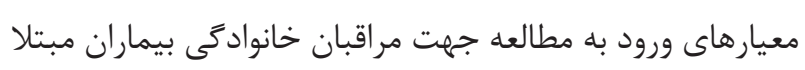

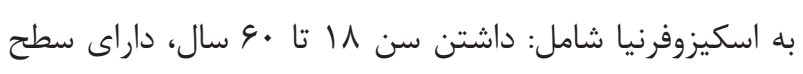

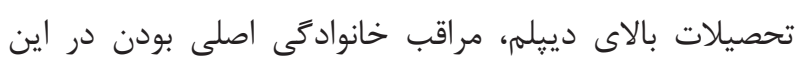

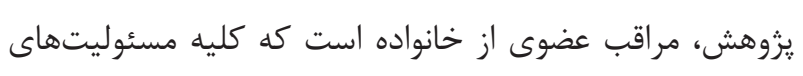

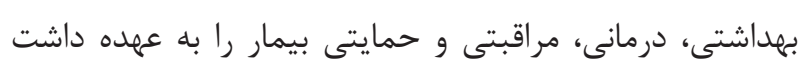

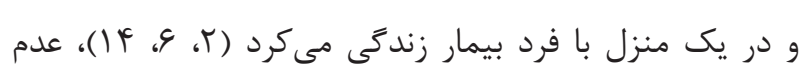
ابتلا به بيمارى روانى شناخته شده، تمايل به شركت در مطالعه،

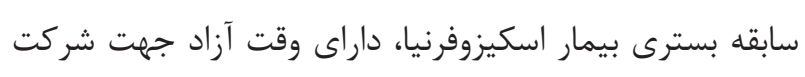

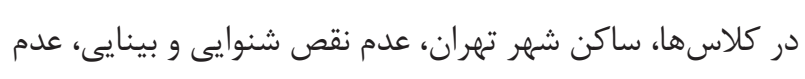

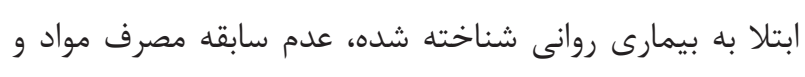
سوء يِشينه، عدم تجربه بحران بزرگى مثل طلاق و مرى عزيزان در شش ماهه اخير. همجنين معيارهاى خروج از مطالعه شامل: انصراف از ادامه مطالعه، ابتلا فرد به بيمارى روانى شناخته شده مده
در آن يادكيرندگان به اندازه ياد دهندگان فعال هستند (11).

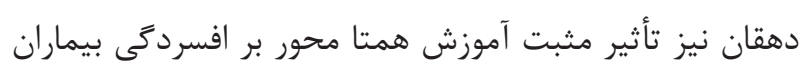

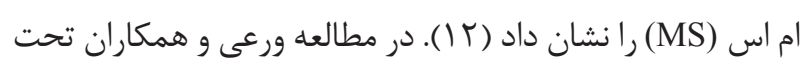

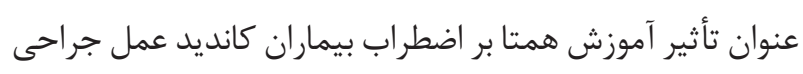

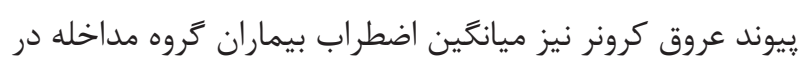

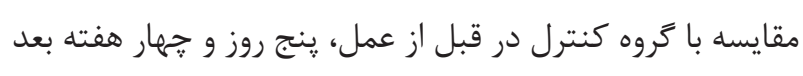

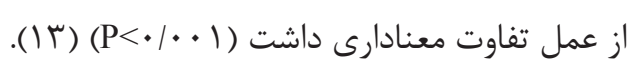
با توجه به محدود بودن مطالعات انجام شده در زمينه بار روانى دانى

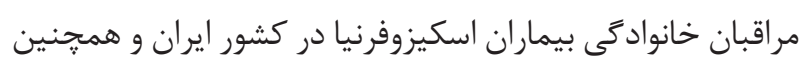

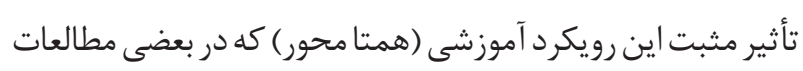
تائيد شده است، اين مطالعه با هدف تعيين تأثير آموزش همتا

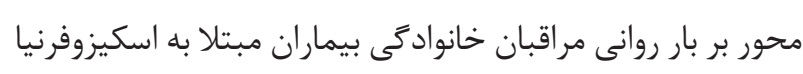

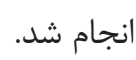

\section{مواد و روش ها}

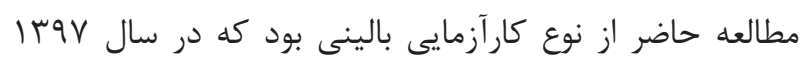

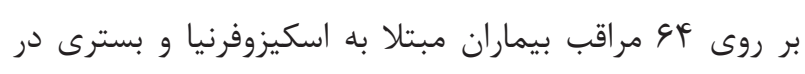
بخشهاى روانى بيمارستانهاى وابسته به نيروهاى مسلح انجام

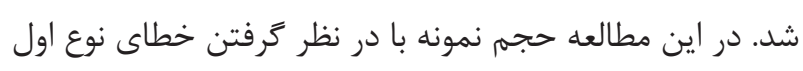

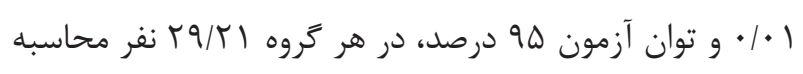

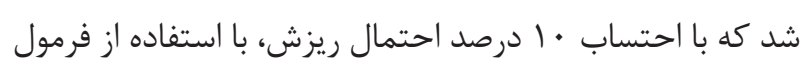

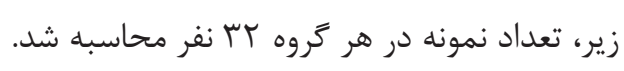

$$
n=\frac{\left(s_{1}^{r}+s_{r}^{r}\right)^{r}\left(z_{1-\frac{\alpha}{r}}-z_{1-\beta}\right)^{r}}{\left(x_{1}-x_{r}\right)^{r}}
$$

$$
\left.N=\frac{\left(\Lambda / r \Lambda r+V / r \Lambda^{r}\right)(I V / \Lambda r)^{r}}{(r q / \Delta r-r \Delta / \Lambda)^{r}}=r q / r\right)
$$

نمونه كيرى به صورت مبتنى بر هدف از ميان خانواده مراجعين

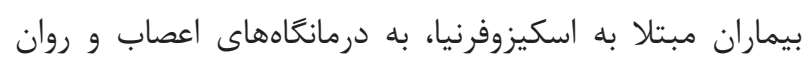

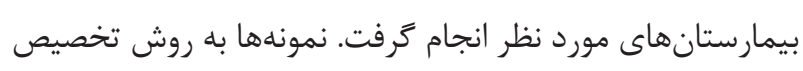

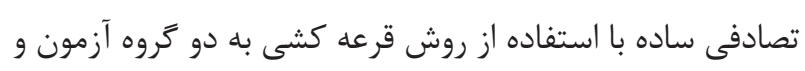
كنترل تقسيم شدند. 
كه از قبل تهيه كرده بود، تحت آموزش قرار داد. در انتهاى جلسه

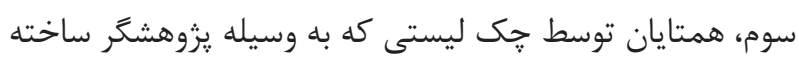

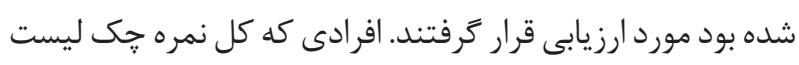
را دريافت كردند جهت آموزش استفاده شدند.

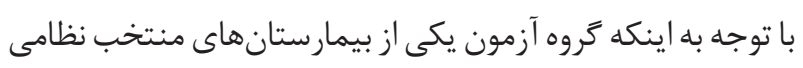

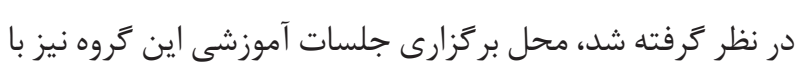

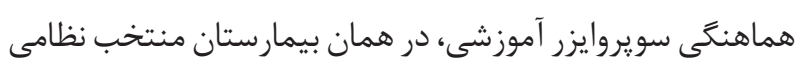

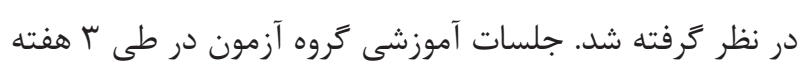

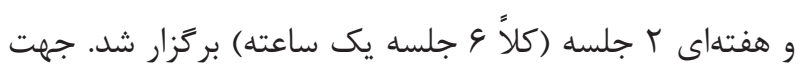

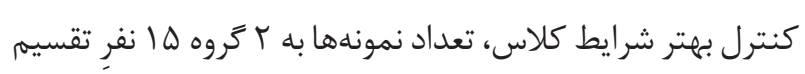

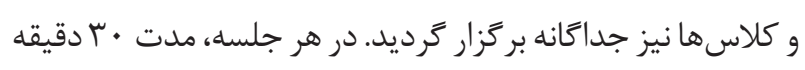

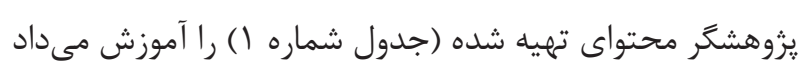

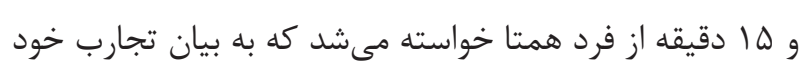

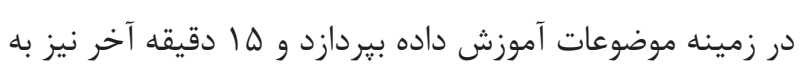
يرسش و ياسخ از شركت كنندهها اختصاص ميى يافت.

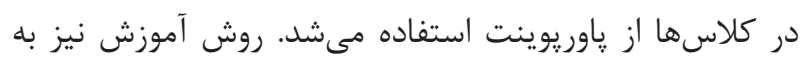

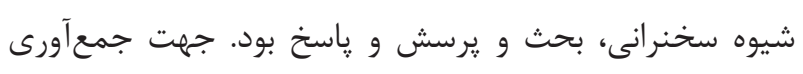

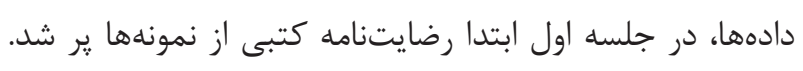

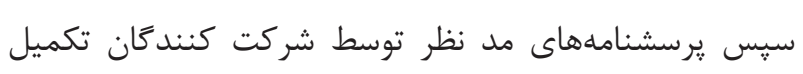

انجام پس آزمون 》استرس عمدهاى" از قبيل طلاق يا مرى

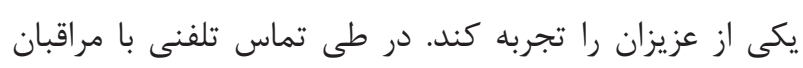

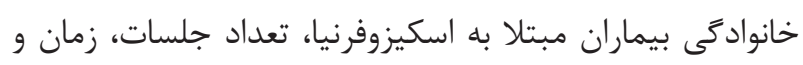

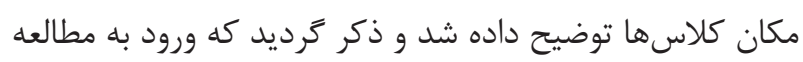

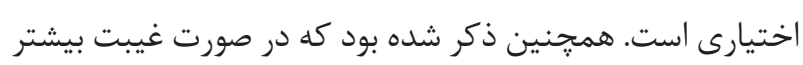

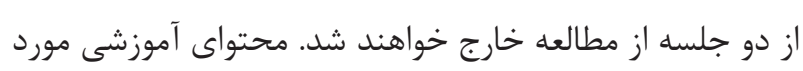
نظر در راستاى كاهش بار روانى مراقبان خانوادگى بيماران مبتلا

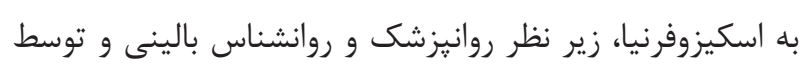

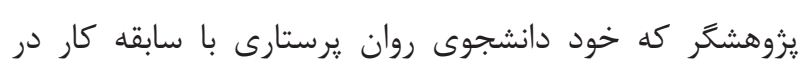
بخشهاى مختلف بيمارستان است تهيه شد. محتواى تهيه شده

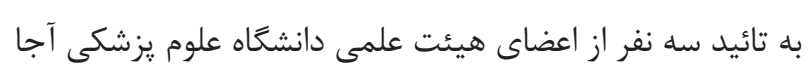

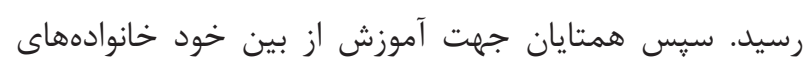

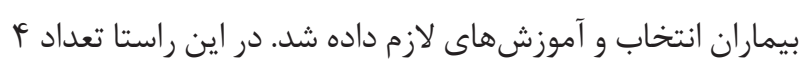

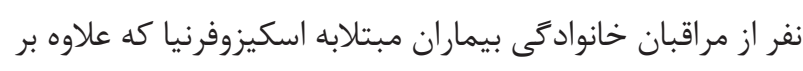

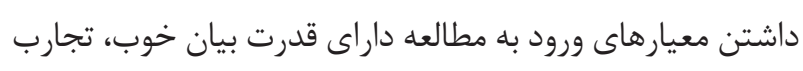

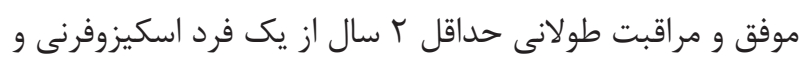

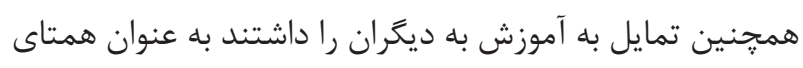

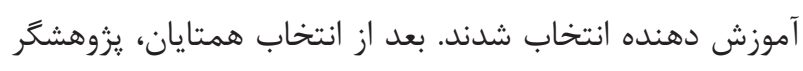

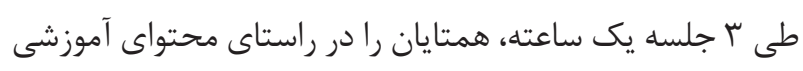

جدول ا- محتواى آموزشى، جلسات در دو كروه مورد مطالعه

\begin{tabular}{|c|c|}
\hline 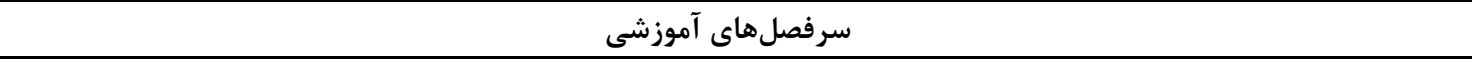 & جلسه \\
\hline 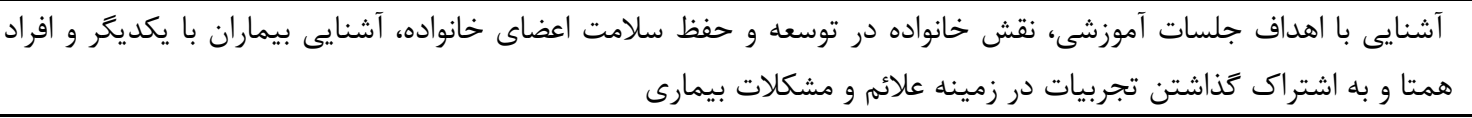 & جلسه اول \\
\hline آشنايى با بيمارى اسكيزوفرنيا، مراقبتهاى مربوط به آنها، اهميت درمان دارويى و نقش آن در پيشكيرى از عود بيمارى. & 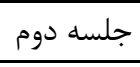 \\
\hline 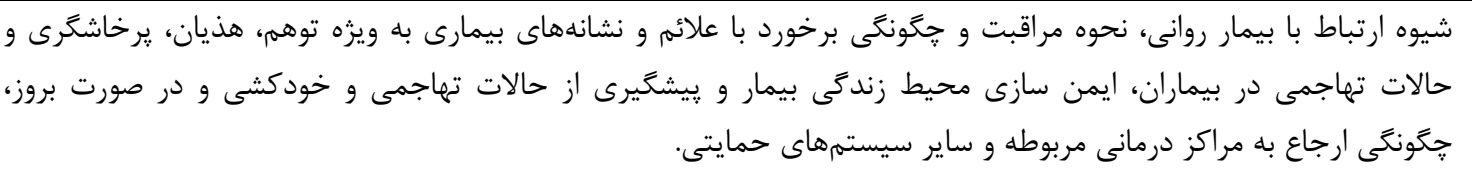 & 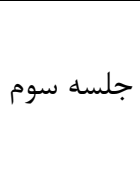 \\
\hline
\end{tabular}

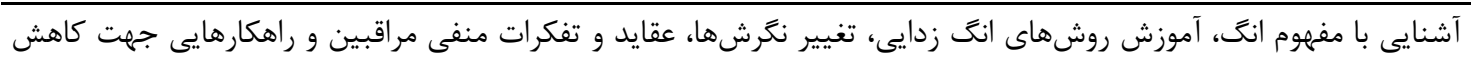
بار روانى مراقبان. جلسه جهارم آشنايى با درمانهاى غير دارويى نظير ورزش، روش انجان انجام صحيح آرام سازى، ماهيت و اهميت آن در جهت جَّونكى كاهش

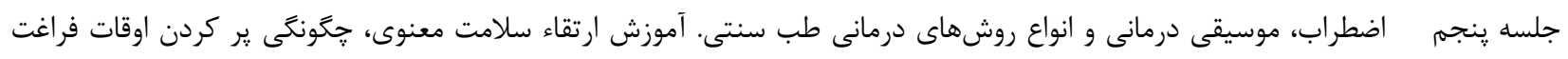

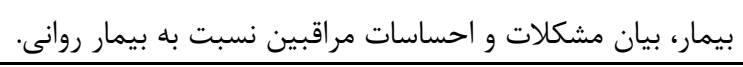

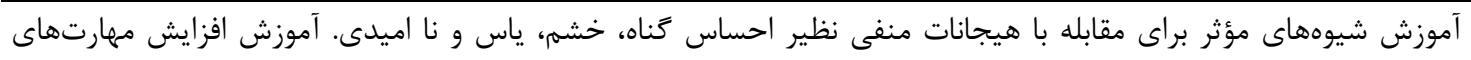

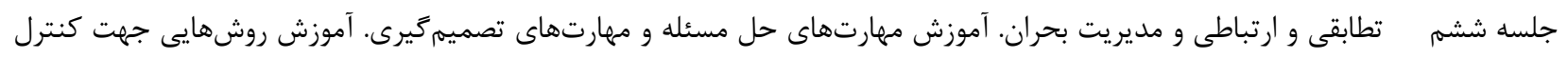

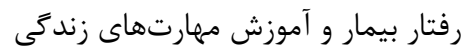




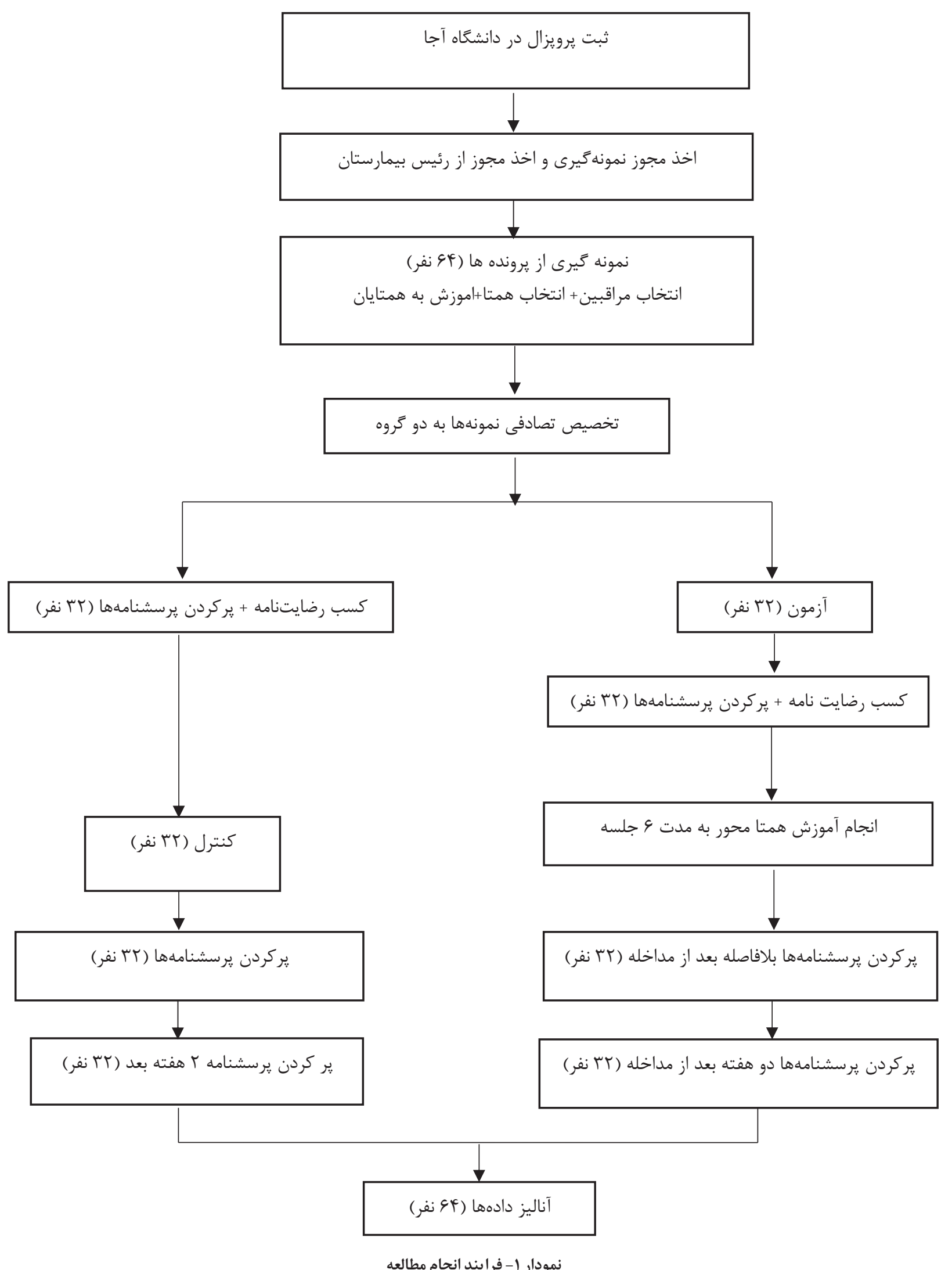


يزوهشكران خود را ملزم به رعايت مفاد هلسينكى (Helsinki)

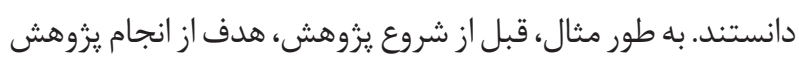

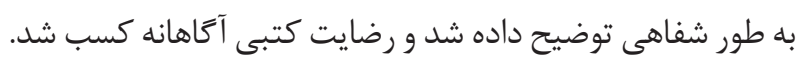
واحدهاى يزوهش در رد يا قبول شركت در مطالعه كاملاً آزاد

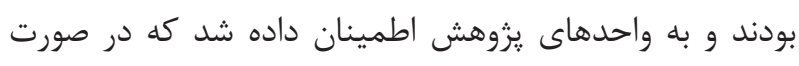

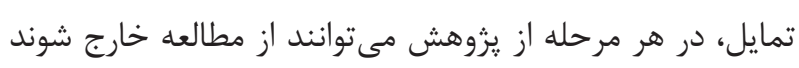
و اين امر در صورت بسترى هيج تأثيرى در مراقبت از بيمارشان نخواهد داشت. رعايت نكات مطرح شده در كميته اخلاق نشر نيز

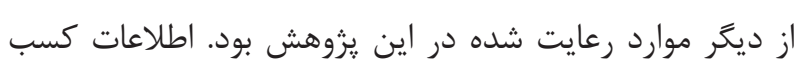

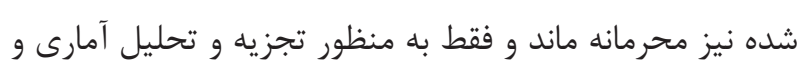

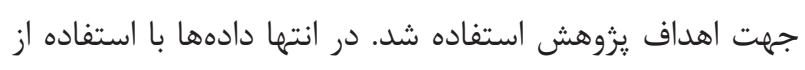

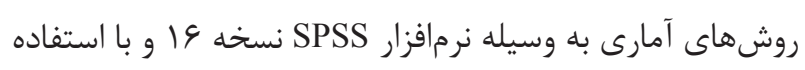

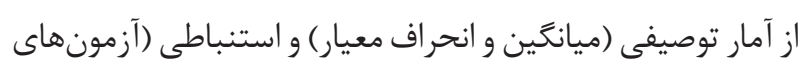

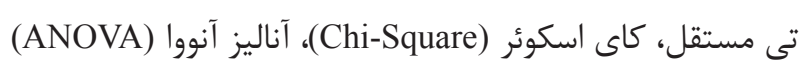

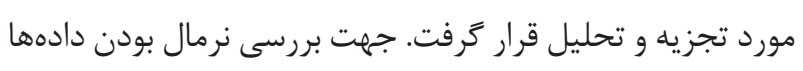
از آزمون كولموَروف اسميرنوف (Kolmogorov Smirnov) استفاده شد. ه • • P به عنوان سطح معنادارى قابل قبول در نظر كرفته شد.

\section{يافتهها}

در مطالعه حاضر تعداد ع \& نفر از مراقبين خانوادگى بيماران

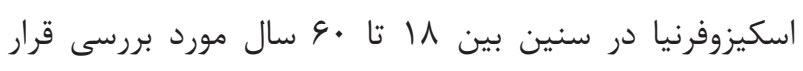

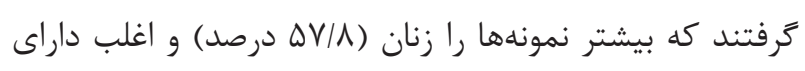

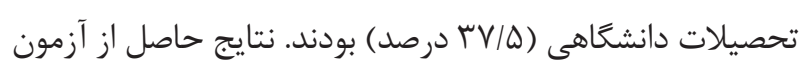
تى مستقل (Independent t-Test) جهت متغيرهاى سن و تعداد دفعات بسترى و آزمون كاى اسكوئر (Chi-Square Test) جهت

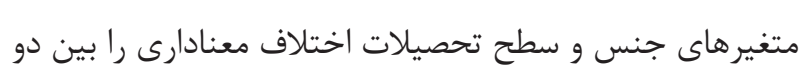

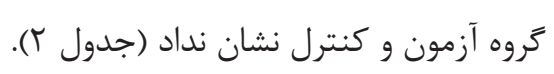

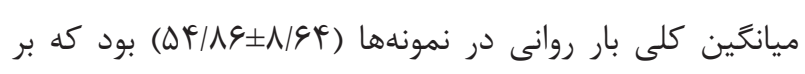

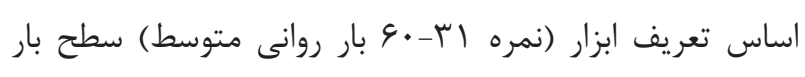

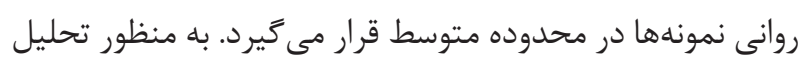

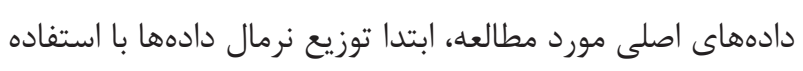

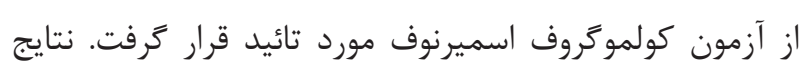

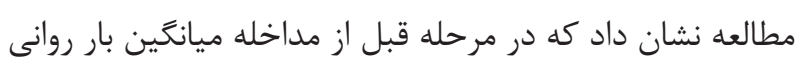

كرديد. سيس در جلسه آخر و r هفته بعد از بركزارى جلسات

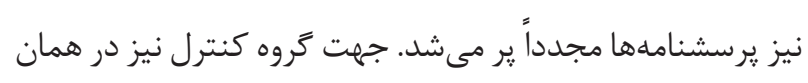

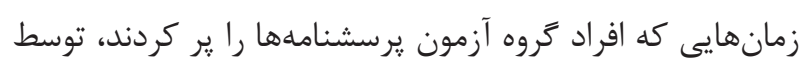

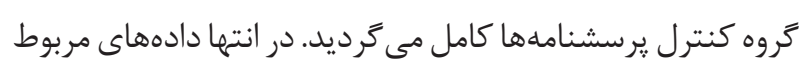

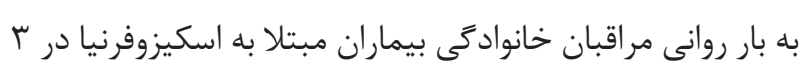

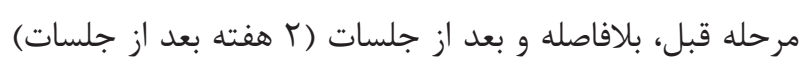

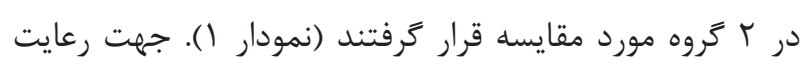

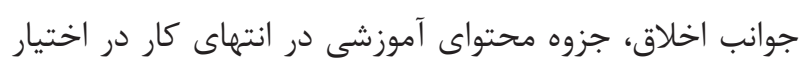
گروه كنترل نيز قرار گرفت.

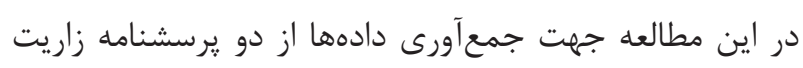
(Zaret)

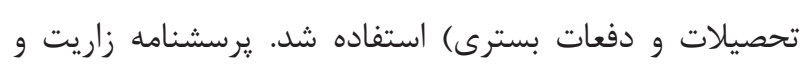

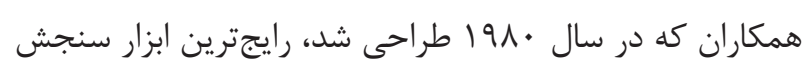

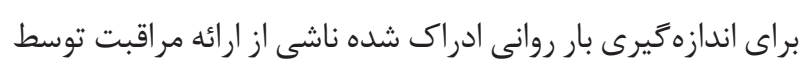

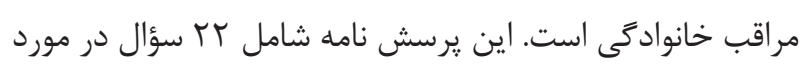

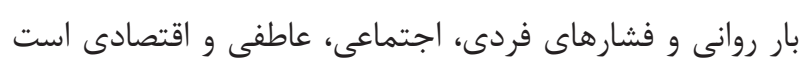

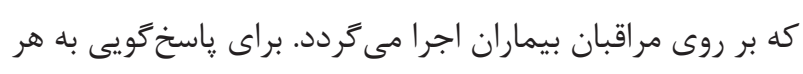

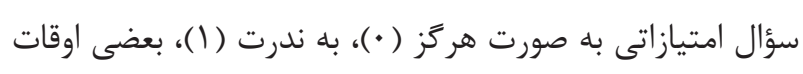

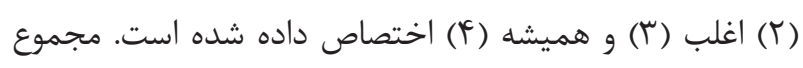
امتيازات كسب شده توسط مراقبان، ميزان فشار و بار روانى كه ونه

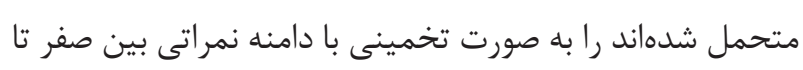

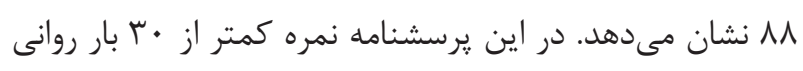

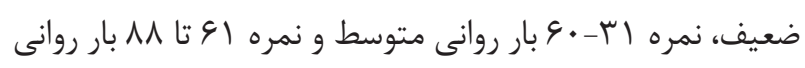

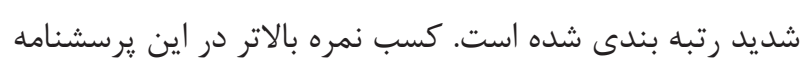

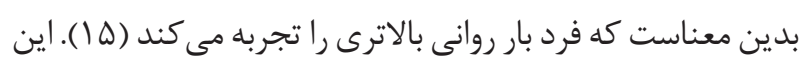

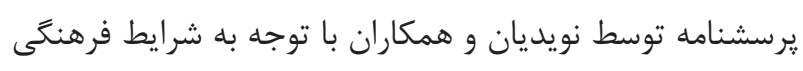

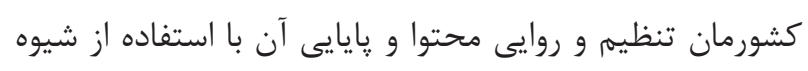

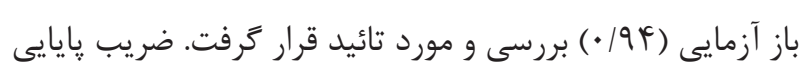

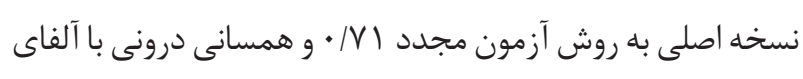
كرونباخ ا9/ • • بوده است (1).

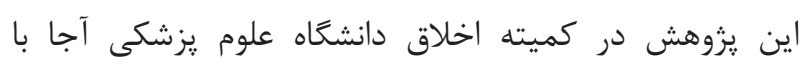

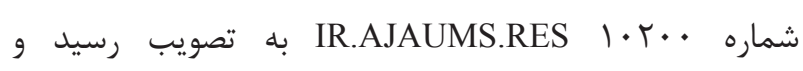

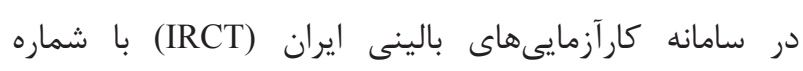

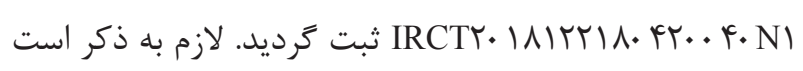


جدول r - مقايسه متغيرهاى دموكرافيك نمونه هاى مورد مطالعه در دو كروه آزمون و كنترل

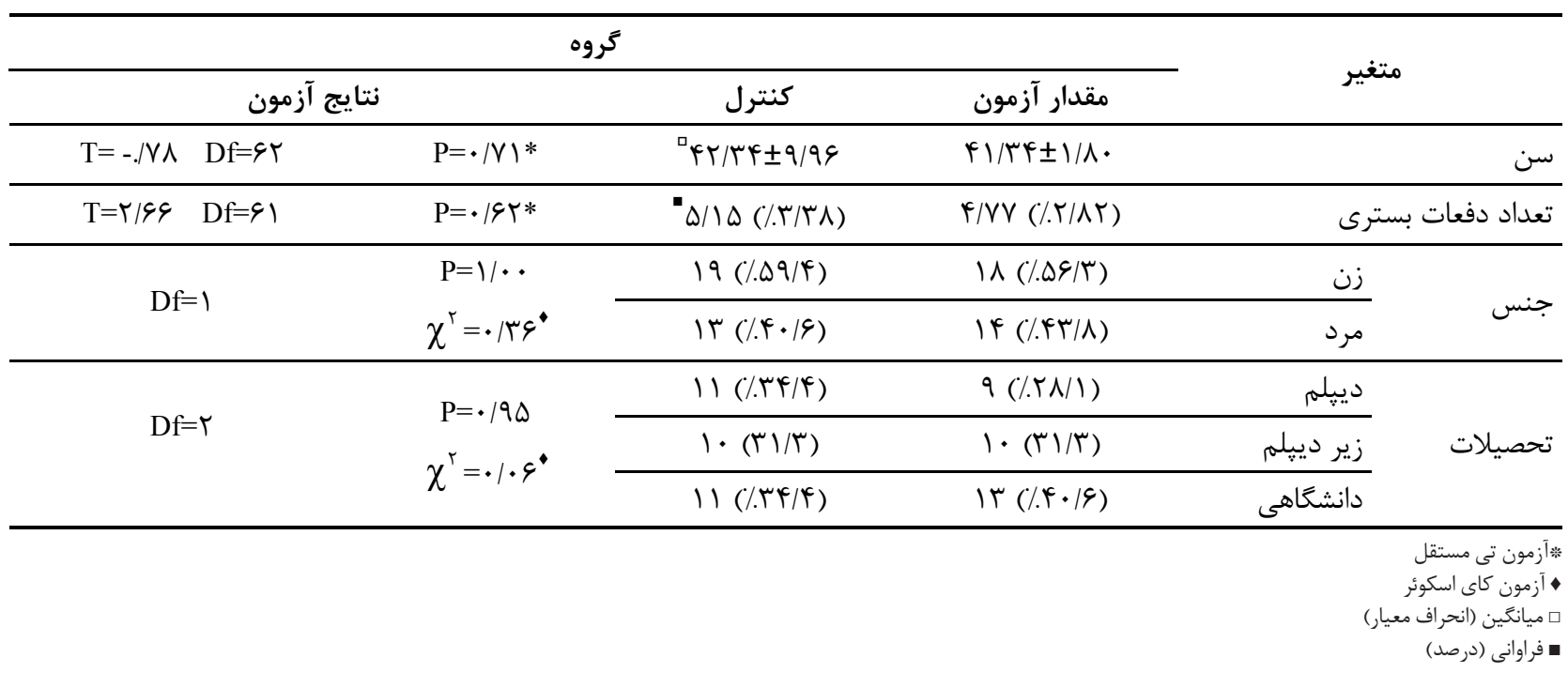

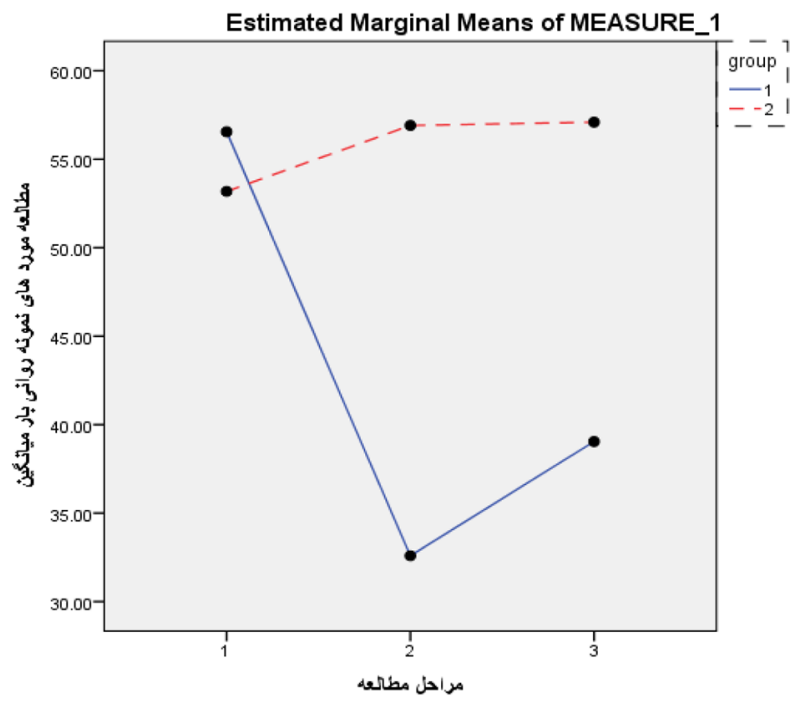

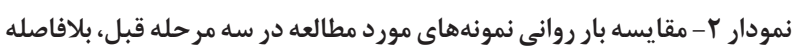

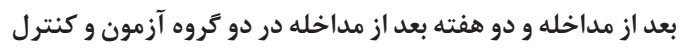
كروه ا: كروه آزمون كروه ז: كروه كنترل
در دو گروه مورد مطالعه با هم اختلاف معنادارى نداشتند. در مرحله بلافاصله بعد از مداخله، همانطور كه در جدول شماره ب درج شده است اختلاف معنادارى ( ( + (P< ) بين كروه آزمون و كنترل در سطح بار روانى مشاهده مىشود. در مرحله دو هفته بعد از مداخله نيز گروه آزمون به طور معنادارى (1 ( P روانى كمترى نسبت به گروه كنترل داشت. نتايج آزمون آنووا نيز به طور معنى (Repeated measures ANOVA) سطح بار روانى دو گروه آزمون و كنترل را در ب مرحله مطالعه

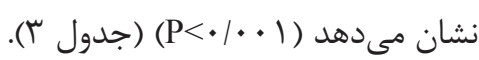
در نمودار شماره r نيز روند نزولى بار روانى در گروه آزمون و روند صعودى بار روانى در گروه كنترل در گذر زمان (در طى سه مرحله مطالعه) نشان داده شده است (نمودار ؟). جدول بـ- مقايسه بار روانى دو كروه آزمون و كنترل در قبل، بلافاصله و دو هفته بعد از مداخله در دو كروه آزمون و كنترل شاخص

\begin{tabular}{|c|c|c|c|c|c|c|}
\hline \multicolumn{2}{|c|}{ دو هفته بعد از مداخله } & \multicolumn{2}{|c|}{ بلافاصله بعد از مداخله } & \multicolumn{2}{|c|}{ قبل از مداخله } & \multirow[t]{2}{*}{ كروه } \\
\hline انحراف معيار & ميانغين & انحراف معيار & ميانغين & انحراف معيار & ميانغين & \\
\hline$\Lambda / \cdot 9$ & $r q / \cdot r$ & $8 / 11$ & Tr/DA & (1/N & $\Delta \varepsilon / \Delta \Delta$ & آزمون \\
\hline 9/^r & $\Delta V / \cdot 9$ & $9 / 19$ & $\Delta \varepsilon / 9$. & N/VQ & $\Delta r / I V$ & كنترل \\
\hline \multicolumn{2}{|c|}{$\mathrm{df}=q r$} & \multicolumn{2}{|c|}{$\mathrm{df}=q \mathrm{r}$} & $\mathrm{df}=9 \mathrm{r}$ & & t نتيجه آزمون \\
\hline \multicolumn{2}{|c|}{$\mathrm{P}<\cdot / \cdots \mathrm{l}$} & \multicolumn{2}{|c|}{$\mathrm{P}<\cdot 1 \cdot .1$} & \multicolumn{2}{|c|}{$\mathrm{P}=\cdot / 1 \mathrm{r}$} & \\
\hline
\end{tabular}

$F=4 \| M / 1 r$ $\mathrm{P}<\cdot / \cdot \cdot$ Repeated measures ANOVA 


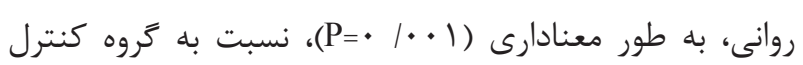

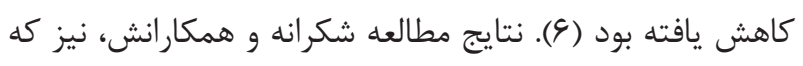

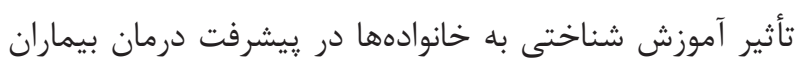

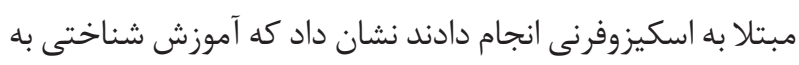

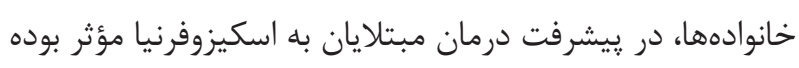

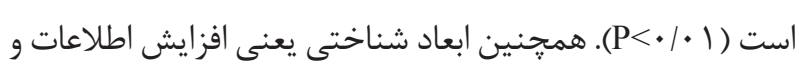

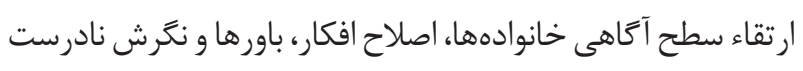
نسبت به اين دسته از افراد در يیشرفت درمان آنان مؤثر بودها

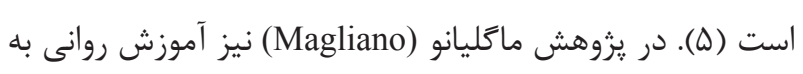

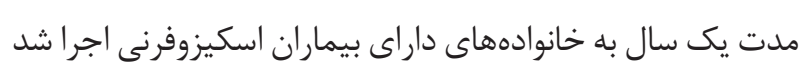

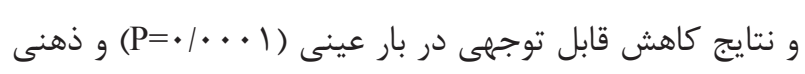

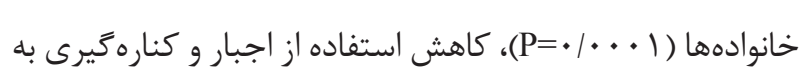

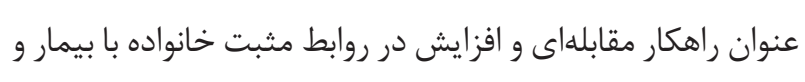

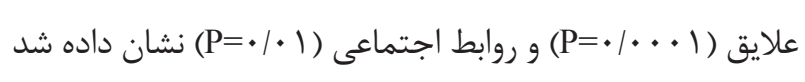

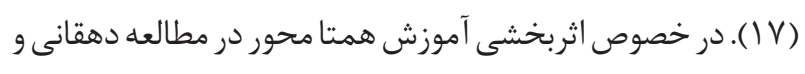

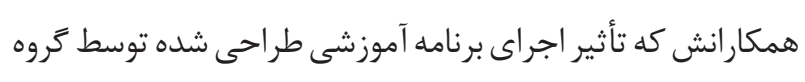

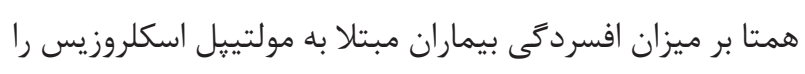

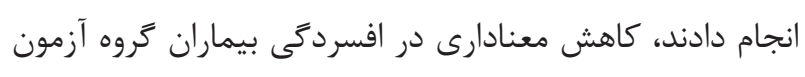

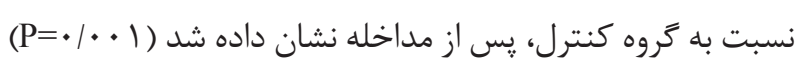

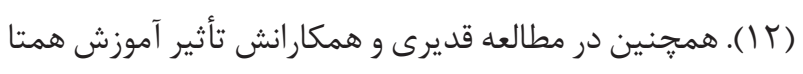

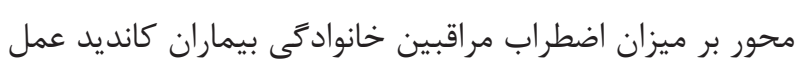

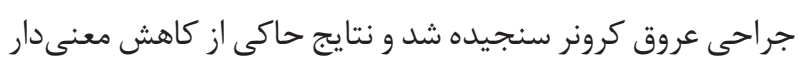

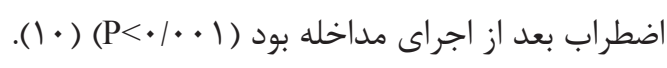

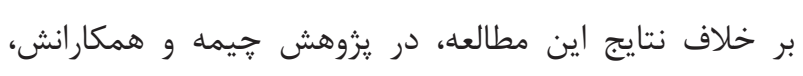
ارتباط معنادارى بين سطح آكاهى مراقبان خانوادههاى مبتلا دئل

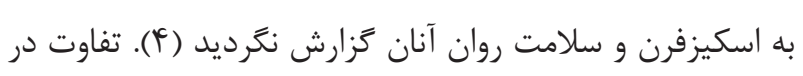

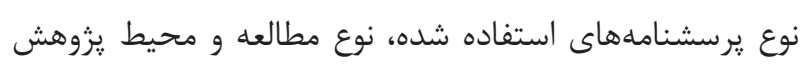

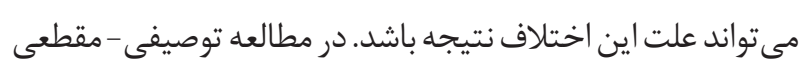

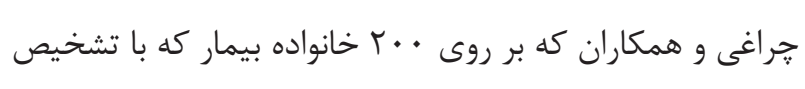
اسكيزوفرنى، اختلالات خلقى اوليه (Primary Mood Disorders) و اختلال وسواس اجبارى (Obsessive Compulsive Disorder) انجام شده بود و به بررسى نيازهاى درمانى و مراقبتى خانواده

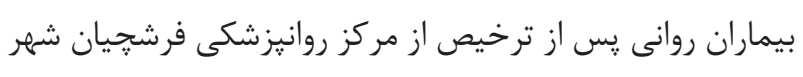

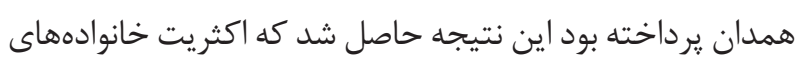

\section{بحث و نتيجه كيرى}

مطالعه حاضر با هدف تعيين تأثير آموزش همتا محور بر بار روانى نيرى نداني مراقبين خانوادكى بيماران اسكيزوفرنيا در شهر تهران انجام شد. نتايج مطالعه نشان داد كه در مرحله قبل از مداخله ميانكَين بار روانى در دو كروه مورد مطالعه با هم اختلاف معنادارى نداشتند.

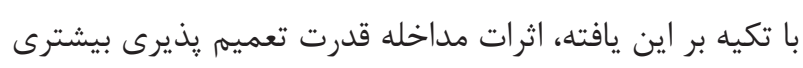

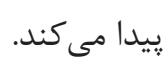
نتايج اين مطالعه نشان داد، سطح بار روانى نمونههاى مورد مطالعه

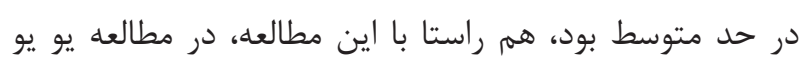
و همكاران كه بر روى (Yu Yu)

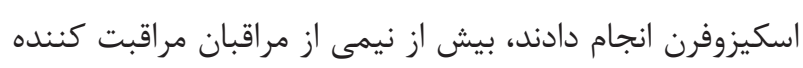

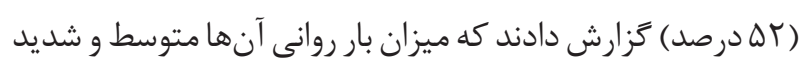
است (91). در مطالعه حارث آبادى و همكارانش نيز كه در سال

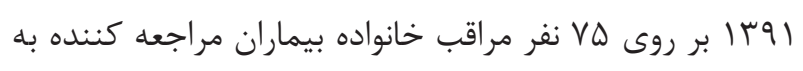

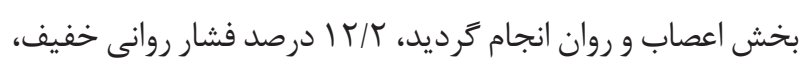

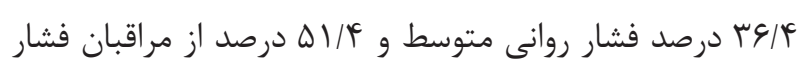
روانى شديد داشتند (r). همجنين در مطالعه نويديان و همكاران

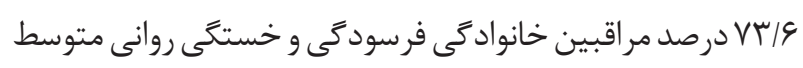
تا شديد گزارش كردند (^).

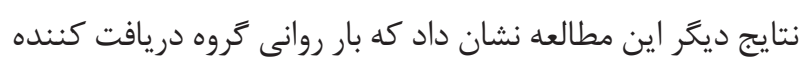

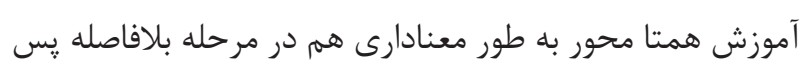

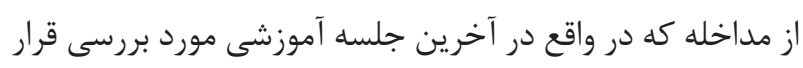

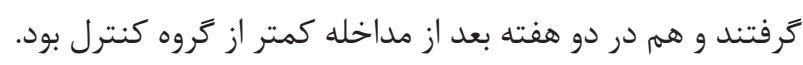

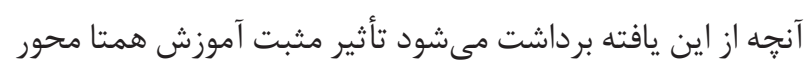

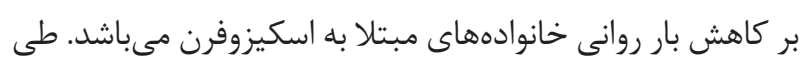
جستجوهاى صورت گرفته توسط يزوهشخر مطالعهاى كه تأثير اين موضوع را بررسى كرده باشند صورت نكرفته است، لذا، در تحليل

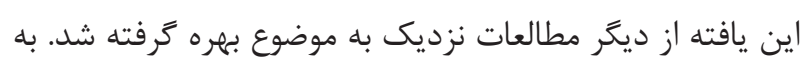

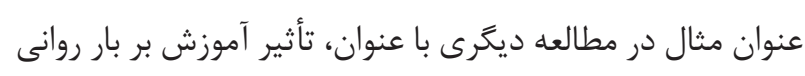

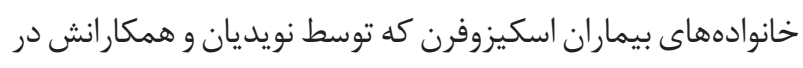
سال شN1 ا اثر بخشى آموزش خانواده بر ميزان بار روانى مراقبان

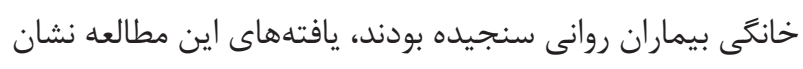

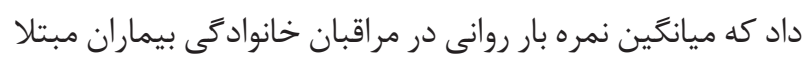

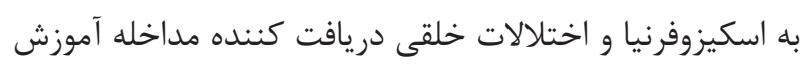




$$
\begin{aligned}
& \text { طول زمان شده بود و گروه كنترل روند صعودى در سطح بار روانى } \\
& \text { در طول زمان داشتند، توصيه مىشود به اين قشر از افراد جامعه } \\
& \text { توجه بيشترى شود و در ييگيرىهاى بعد از ترخيص خانوادهها و } \\
& \text { حتى در حين بسترى بودن اين دسته از بيماران، از يتانسيلهاى } \\
& \text { افراد با تجربه در اين زمينه استفاده گردد و آموزش داده شود. }
\end{aligned}
$$

$$
\text { تشكر و قدردانى }
$$

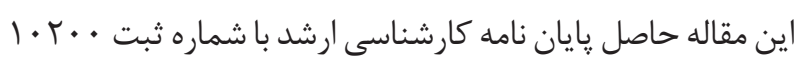

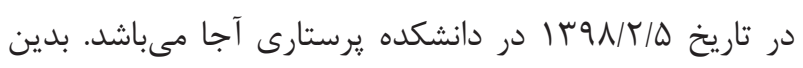
وسيله از مسئولين محترم يزوهش دانشكده يرستارى آجا، اساتيد

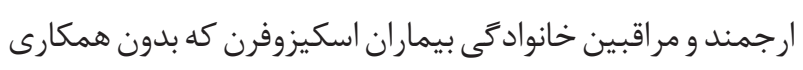
آنها اين تحقيق ممكن نبود، نهايت سياسگزارى و كمال تشكر

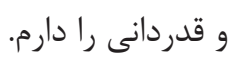

\section{تضاد منافع}

بدين وسيله نويسندكًان تصريح مىنمايند كه هيجگًونه تضاد

$$
\text { منافعى در يزوهش حاضر وجود ندارد. }
$$

\section{References}

1- Kushan M, Vaghei S. [Psychiatric Nursing: Mental Health 2]. Tehran: Andisheh Rafi; 2015.

2- Haresabadi M, Bibak B, Hosein zadeh E, Bayati M AM, Akbari H. [Assessing burden of family caregivers of patients with schizophrenia Admitted in Imam REZA hospital- Bojnurd]. JNKUMS. 2012;4(2):165-71.

3- Haji Aghaei N, Sheikhi M R, Zeighami R, Alipour M. [Follow up of the impact of family-centered psychoeducation based on Atkinson and Coia's model on the relapse and severity of symptoms in schizophrenia]. IJPN. 2017;5(4):27-33.

4- Chimeh N, Malakoti SK, Panaghi, Ahmad Abadi Z, Nojomi N, Ahmadi Tonkaboni. [Care Giver Burden and Mental Health in Schizophrenia]. Journal of Family Research 2008;4(3):277-92.

5- Shokraneh E, Ahmadi SA. [The effects of family cognitive training on improving the treatment of schizophrenic patients]. Journal of Family Research. 2009;5(1):17-28.

6- Navidian A, Pahlavanzadeh S, Yazdani M. [The effectiveness of family training on family caregivers of inpatients with mental disorders]. IJPCP. 2010;16(2):99-106.

7- Torabi ZS, Eghlima M, Khanke HR, Reza Sotani P, Yazdani AA. [Family burden and family function Patients with chronic mental disorders. Social Welfare Quarterly]. 2013;13(51):133-49.

TQ 8- Navidian A, Salar A, Hashemi Nia A, Keikhaei A. [Study of
بيمار ان روانى نيازهايى مانند مشاوره منظم توسط متخصص، ارائه مراقبت در جامعه، پيخيرى درمان پس از ترخيص، آموزش به بيمار و خانواده، بازتوانى روانى و اجتماعى را مهمم مى دانستند (1) (1). در يك جمعبندى كلى از مطالعات ذكر شده و همجنين با توجه به نتايج اين مطالعه، مىتوان اظهار داشت كه آموزش مى تواند يكى مداخله مؤثر در كاهش بار روانى مراقبين بيماران روان باشد. اين مطالعه با محدوديتهايى از جمله محدود بودن فرصت يزوهشگر جهت انجام طرح كه متعاقباً منجر به كوتاه در نظر گرفتن دوره آموزشى شده بود مىباشد. وجود تفاوتهاى فردى، وضعيت روحى و روانى واحدهاى يروهش در هنًَام ياسخ گَويى به سؤالات مى توانست بر نحوه ياسخ گُويى آنها اثر بحذارد. همجنين مشكلات خانوادگى، اجتماعى و اقتصادى واحدهاى يزوهش كه كنترل كامل آنها از عهده يزوهشخر خارج بوده است. با توجه به اينكه سطح بار روانى نمونههاى اين مطالعه در سطح

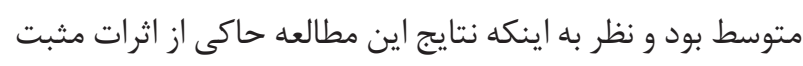
آموزش همتا محور بر بار روانى خانوادههاى بيماران مبتلا به

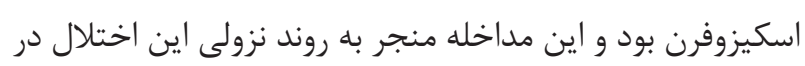

mental exhaustion experienced by family caregivers of patients with mental disorders. Zahedan Psychiatric Hospital]. JBUMS. 2001;3(4):33-8.

9- Mohammad Poorhodki R, Rahnama M, AbdollahiMohammad A, Shahraki vahed A, Shaamsizadeh M. [A comparison of the effect of training by peers and nurses on anxiety in patient with myocardial infarction: a randomized control trial]. PCNM. 2016;6(3):12-23.

10- Ghadiri E, Shahriari M, Maghsoudi J. [The effects of peerled education on anxiety of the family caregivers of patients undergoing coronary artery bypass surgery $(\mathrm{CABG})$ in Shahid Chamran center Isfahan University of Medical Sciences]. IJPN. 2016;4(2):50-6.

11- Eslami R, Sajadi S A, Farsi Z. [Comparing the effect of peer education and orientation tour on the stress of patients candidate for coronary angiography in selected hospital of AJA University of Medical Sciences]. J Urmia Nurs Midwifery Fac. 2015;12(12):1119-27.

12- Dehghani A, Kermanshahi S, Memarian R, Hojjati H, Shamsizadeh M. [The effect of peer-led education on depression of multiple sclerosis patients]. Psychiatric Nursing.1(1):63-71.

13- Varaei S, Cheraghi M, Seyedfatemi N, Talebi M, Bahrani N, Dehghani A, et al. [Effect of peer education on anxiety in patients candidated for coronary artery bypass graft surgery: A randomized 
control trial]. 3 JNE. 2013;2(3):28-37.

14- Vaghee S, Salarhaji A, Asgharipour N, Chamanzari H. [Effects of psychoeducation on stigma in family caregivers of patients with schizophrenia: A Clinical Trial]. Evidence Based Care Journal. 2015;5(16):63-76.

15- Smith AM, Schwirian PM. The relationship between caregiver burden and TBI survivors' cognition and functional ability after discharge. Rehabil Nurs. 1998;23(5):252-7.

16- Yu Y, Liu Z W, Tang B W, Zhao M, G. LX, Xiao S Y. Reported family burden of schizophrenia patients in rural China. PLoS ONE 2017;12(6): e0179425.
17- Magliano L, Fiorillo A, Fadden G, Gair F, Economou M, Kallert $\mathrm{T}$, et al. Effectiveness of a psychoeducational intervention for families of patients with schizophrenia: preliminary results of a study funded by the European Commission. World Psychiatry. 2005;4(1):45-9.

18- Cheraghi F, Shamsai F, Ryazi H. [Study of the treatment and care needs of the family of psychiatric patients after discharge from the center Mashhad Psychoanalysis]. Scientific Journal of Hamadan Nursing \& Midwifery Faculty. 2010;18(2):15-25. 